\title{
A STUDY ON IMPROVING THE DISTRIBUTION PROCESSES. THE CASE OF MIRUNA INTERNAŢIONAL IMPEX LTD.ROMANIA
}

\author{
Andreea Cristina BEJINARIU, Paula GANEA, \\ Mădălina LEUCA, Florian MUNTEAN \\ Politehnica University of Timisoara, Romania \\ bejinariu_andreea_cristina@yahoo.com, heiuspaula@gmail.com \\ leucamadalina93@gmail.com, munteanflorian@yahoo.com
}

\begin{abstract}
Investing is a category of spending that engages the future most, depends on increasing and improving the productive potential of an enterprise (through expansion and modernization), the emergence of new production capacities. Because it is necessary to allocate large resources for the investment process, they are for a long time and the decision making process involves a lot of uncertainties. A decision on investment projects must be based on a careful analysis of all aspects of the context, the variables involved and their dynamics.
\end{abstract}

Keywords: investment, economic efficiency indicators, analysis, options, project

\section{Introduction}

The company's main process that support its development is the investment. This help the company to cope with the growing competition on the market, to meet contract terms without problems and to reduce costs related to production and distribution by solving the most important problem offacing any company's resistance the market competition. Implementing an investment process involves overcoming the main obstacles as: the uncertainties, responsibility and the associated risks. All these aspects fade away when a successful implementation of the investment project is achieved. Innovation within an organization depends on the capacity of the existing intellectual capital to make decisions [7].

The complexity of the decision-making process requires a preliminary, well documented stage and a strategy for obtaining as much information as possible [1-4]. All actions (documentation, estimations, and calculations) should be planned but also followed well-defined steps included in a well-defined methodological approach. In addition, all possible risks arising from investments must be taken into account and estimated and, finally, some clear project evaluation methods should be applied[6]. The result of evaluating an investment project depends on three variables: time, liquidity and risk mitigation aspects. The risk assessment process related to the investment projects is necessary to avoid delays and losses in all categories[5].

The project should have the ability to generate profit therefore should allow overall return of investment. Characteristics of the investment project will fit into the following categories:

- Strategic Investments - is the company's strategy and refers to creating a new product / service or various alliances between companies;

- Investment expansion refers to organization's management option on growing or expanding the production capacity or through mergers and acquisition investments; 
- Investment through the modernization of the existing organization capacity or processes refers to investments developed in order to up-date the means of production, in order to increase their productivity, working time;

- Investments in human capital development are associated with the highest risk and uncertainties rates, and usually refers to employees' competencies and skills development through specialized training programs.

In this context, an investor has to fundament the decision making processes on scientific basis in order to make the best decision choices for a related organization where the investment process took place. In this case, in order to diminish (or avoid) the uncertainties associated with the decision making process, there is mandatory to have a preliminary diagnosis of the organization, considering the state of all functions (internal environment) that should be understood in relation with the external environment specificity and dynamics. The initial diagnosis of the organization should be developed by the top management team in order to generate a global, real and pertinent imagine on the whole system.

In the following chapter there will be described the proposed methodology and its practical usefulness through a case study.

\section{Methodological approach}

The previous work of [5] has described in generally how classical methods and tools can be combined in order to get a well scientific fundament for the decision making process for investments, related to a company. The preliminary presented methodology has only make the preparation for the economic efficiency analysis of the potential investment projects. Thus, the aim of this paper is to show how the hierarchy of the potential investments projects can be established based on the calculations of the economic efficiency indicators. The proposed methodology is shown in Figure 1.

\begin{tabular}{|l|}
\hline $\begin{array}{c}\text { 1. Collecting and } \\
\text { structure the in-put data } \\
\text { for each investment } \\
\text { project }\end{array}$ \\
\hline \multicolumn{1}{c|}{ - Relevant in-put data: The } \\
investment capital; The \\
distribution capacity of \\
the merchandise; Unit \\
cost of distribution; Unit \\
price for sale; Execution \\
time of the investment \\
works; Effective \\
operating time, etc. \\
\end{tabular}

\section{Investments economic efficiency - dynami analysis \\ - Relevant indicators: Investment capital discounted value; Profit discounted value; Return of investment discounted value; Recovery term of investment discounted value}

Figure 1: The proposed methodology for establishing the investment projects hierarchy

\section{Case study: The investment decision making process in the case of MIRUNA INTERNATIONAL IMPEX Ltd.}

The proposed methodology (Figure 1) will be tested in validated through a case study. MIRUNA INTERNATIONAL IMPEX Ltd. (http://www.miruna-international.ro/) is a Romanian company operating in the wholesale trade economic filed. Products'distribution is ensured through their own logistics fleet, delivery time being 24 hours from receipt.The company wants to invest for newtruck fleet to improve the transport of goods to customers in a shorter time, but also to reduce the cost of transport (fuel, repairs). The source of investment financing is in equity.For the investment 
process implementation, the following three offers were analysed, and the optimum option has be chosen:

- Option 1: investment for two Iveco trucks, model Stralis260S31;

- Option 2: the purchase of two Scania Streamline trucks is foreseen;
- Option 3:investment for two Man TGL 12.220 Stake Body Tarpaulin Tailgate Euro V.

Table 1 shows the cost analysis for the three investment options.

Table 1 Cost analysis for the three investment options (for one truck, lei)

\begin{tabular}{|l|l|l|l|l|}
\hline Investment options & Maintenance & Truck trailer & Truck & Total amount \\
\hline Inv 1 & 320000 & 1300000 & 3500000 & 5120000 \\
\hline Inv 2 & 280000 & 1500000 & 4250000 & 6030000 \\
\hline Inv 3 & 160000 & 1100000 & 2750000 & 4010000 \\
\hline
\end{tabular}

Table 2 Input data for the project investments comparison

\begin{tabular}{|l|l|l|l|l|l|}
\hline Indicator & Symbol & Unit & Inv 1 & Inv 2 & Inv 3 \\
\hline The investment capital & $\mathrm{Inv}$ & $\mathrm{RON}$ & 10240000 & 12060000 & 8020000 \\
\hline $\begin{array}{l}\text { The distribution capacity of } \\
\text { the merchandise }\end{array}$ & $\mathrm{Cd}$ & $\mathrm{t} / \mathrm{year}$ & 20000 & 20000 & 20000 \\
\hline Unit cost of distribution & $\mathrm{C}$ & $\mathrm{RON} / \mathrm{t}$ & 300 & 270 & 230 \\
\hline Unit price for sale & $\mathrm{P}$ & $\mathrm{RON} / \mathrm{t}$ & 1300 & 1100 & 1000 \\
\hline $\begin{array}{l}\text { Execution time of the } \\
\text { investment works }\end{array}$ & $\mathrm{D}$ & year & 4 & 5 & 6 \\
\hline Effective operating time & $\mathrm{De}$ & year & 10 & 10 & 9 \\
\hline
\end{tabular}

The company has organized a tender process for choosing the optimal investments solution, based on theeconomic efficiency analysis related to three possible investment projects that are characterized by the input data shown in Table 2 . The static analysis of the economic efficiency is based on the calculation the proposed relevant indicators, whichcharacterized the amounts spent for each investments, reflecting the progress of activities, underlined the strengths and weakness of each investment projects, as shown in Table 3 (bold values are the optimum one for an analyse indicator). Related to each economic indicator analysis, the score 1 was given for the optimum investment project. The total score was calculated by summing the individual scores gained by an investment option or project per each indicator included in the analysis.

Table 3 indicators of economic efficiency of investment in static vision

\begin{tabular}{|l|c|c|c|c|c|c|c|}
\hline \multicolumn{1}{|c|}{ Indicators } & Unit & Inv 1 & Inv 2 & Inv 3 & Score 1 & Scor 2 & Scor 3 \\
\hline $\begin{array}{l}\text { The investment } \\
\text { capital }\end{array}$ & RON & 10240000 & 12060000 & $\mathbf{8 0 2 0 0 0 0}$ & 0 & 0 & 1 \\
\hline $\begin{array}{l}\text { The duration of } \\
\text { the investment } \\
\text { project } \\
\text { implementation }\end{array}$ & year & $\mathbf{4}$ & 5 & 6 & 1 & 0 & 0 \\
\hline $\begin{array}{l}\text { Efficient } \\
\text { exploitation time }\end{array}$ & year & $\mathbf{1 0}$ & $\mathbf{1 0}$ & 9 & 1 & 1 & 0 \\
\hline
\end{tabular}




\begin{tabular}{|l|c|c|c|c|c|c|c|}
\hline $\begin{array}{l}\text { Specific } \\
\text { investment }\end{array}$ & $\begin{array}{c}\text { RON } \\
/ \mathrm{t}\end{array}$ & 512 & 603 & $\mathbf{4 0 1}$ & 0 & 0 & 1 \\
\hline $\begin{array}{l}\text { Investment } \\
\text { productivity }\end{array}$ & $\begin{array}{c}\text { RON } \\
/ \mathrm{t}\end{array}$ & 195313 & 165837 & $\mathbf{2 4 9 3 7 7}$ & 0 & 0 & 1 \\
\hline Annual incomes & RON & $\mathbf{2 6 0 0 0 0 0 0}$ & 22000000 & 20000000 & 1 & 0 & 0 \\
\hline $\begin{array}{l}\text { Annual cost of } \\
\text { distribution }\end{array}$ & RON & 6000000 & $\mathbf{5 4 0 0 0 0 0}$ & 4600000 & 0 & 1 & 0 \\
\hline Annual profit & RON & $\mathbf{2 0 0 0 0 0 0 0}$ & 16600000 & 15400000 & 1 & 0 & 0 \\
\hline $\begin{array}{l}\text { Recovery term } \\
\text { of investment }\end{array}$ & year & $\mathbf{0 . 5 1}$ & 0.73 & 0.52 & 1 & 0 & 0 \\
\hline $\begin{array}{l}\text { Economic } \\
\text { efficiency } \\
\text { coefficient }\end{array}$ & - & $\mathbf{1 . 9 5}$ & 1.38 & 1.92 & 1 & 0 & 0 \\
\hline $\begin{array}{l}\text { Return of } \\
\text { investment }\end{array}$ & - & $\mathbf{1 8 . 5 3}$ & 12.76 & 16.28 & 1 & 0 & 0 \\
\hline $\begin{array}{l}\text { Equivalent } \\
\text { expenditure }\end{array}$ & RON & 70240000 & 66060000 & $\mathbf{4 9 4 2 0 0 0 0}$ & 0 & 0 & 1 \\
\hline $\begin{array}{l}\text { Annual } \\
\text { equivalent } \\
\text { expenditure }\end{array}$ & $\begin{array}{l}\text { RON } \\
\text { year }\end{array}$ & 7024000 & 6606000 & $\mathbf{5 4 9 1 1 1 1}$ & 0 & 0 & 1 \\
\hline $\begin{array}{l}\text { Specific } \\
\text { equivalent } \\
\text { expenditure }\end{array}$ & $\begin{array}{l}\text { RON } \\
\text { year }\end{array}$ & 351 & 330 & $\mathbf{2 7 5}$ & 0 & 0 & 1 \\
\hline & \multicolumn{2}{|l|}{} & & 7 & 2 & 6 \\
\hline
\end{tabular}

From the static analysis of the economic efficiency (Table 3), it can be seen that all three investment projects have bothadvantages and disadvantages, and the option 1 seems to be better that option 3, obtained close scores. For a clear distinction of options 1 and 3 there have to beanalysed the economic efficiency indicators of the investment using the dynamic vision. This advanced approach is based on the calculations of relevant discounted indicators of efficiency using the principle of compound interest (interest computed on the principal amount to which interest earned to-date has been added; where compound interest is applied, the investment grows exponentially). In this context, the economic performance indicators in dynamic vision resulting from the calculations reflect the influence of the time factor, because the evolution of the processes is taken into account. The calculation results of the most important indicators are shown in Table 4(bold values are the optimum one for an analyse indicator).

Table4 Indicators of economic efficiency of investment -dynamic vision

\begin{tabular}{|c|l|c|c|c|c|c|}
\hline$\#$ & \multicolumn{1}{|c|}{ Indicator } & Symbol & Unit & Option 1 & Option 2 & Option 3 \\
\hline 1 & $\begin{array}{l}\text { Investment capital } \\
\text { discounted value }\end{array}$ & Inv & RON & $\mathbf{4 2 1 0 1 6 6 . 2 9}$ & 5534924.44 & 6940053.87 \\
\hline 2 & Profit discounted value & Pd & RON & $\mathbf{1 9 2 2 0 7 1 . 7 3}$ & 645857.44 & 1074983.28 \\
\hline 3 & $\begin{array}{l}\text { Return of investment } \\
\text { discounted value }\end{array}$ & ROId & - & $\mathbf{0 . 4 6}$ & 0.12 & 0.15 \\
\hline
\end{tabular}




\begin{tabular}{|c|l|c|c|c|c|c|}
\hline 4 & $\begin{array}{l}\text { Recovery term of } \\
\text { investment discounted } \\
\text { value }\end{array}$ & $\mathrm{Td}$ & Years & 0.7 & 10.94 & 9.12 \\
\hline 5 & Discount rate & $\mathrm{a}$ & $\%$ & 15 & 15 & 15 \\
\hline 6 & $\begin{array}{l}\text { The average economic } \\
\text { efficiency factor on the } \\
\text { economic field }\end{array}$ & $\mathrm{e}_{\mathrm{n}}$ & $\%$ & 35 & 35 & 35 \\
\hline
\end{tabular}

Following the calculation of economic efficiency indicators in a dynamic vision, MIRUNA INTERNATIONAL IMPEX Ltd. Companywill decide on implementing Option 1 investment project. As a result of this project implementation, the company will have an updated profit of 1922071.73 lei, with a return of investment of 8 months and 12 days.

\section{Conclusion}

The investment projects study has been developed from the perspective of many sciences as: strategic management, project management, production and operations management, management accounting and financial management. From the perspective of the described approach, there have been combined the financial management and management accounting with relevant aspects of operations management in order to better collect the input data for the calculations of the economic efficiency indicators.

The aim of the paper was to present and validate a proposed methodology for the investment project analysis and their hierarchy establishment. For the purpose of the proposed methodology application into the economic practice, there have been proposed a set of minimum relevant indicators for both the investmentprojects economic efficiency analysis using the static and the dynamic perspective.

The proposed methodology has been tested and validated through a case study of a company operating in the operating in the wholesale trade economic filed. In this case, the applied methodology together with the related proposed calculations have support the company's management option for the first proposed investment project: acquisition of two Iveco trucks, model Stralis 260S31 that will better support the product's transport to customers (with lower cost of transport, with minimum impact on the environment, with transport time reduction etc.).

In conclusion, the proposed methodology for the analysis of theinvestment projects has been proved to be a useful one in order to support the decision making process for the optimum alternative.

[1] Draghici, A. andDobrea R. C., Engineering and Management Investment, PolitehnicaPublishing House, Timisoara, 2012.

[2] Hansen, M. T., Nohria, N., and Tierney, T., What's your strategy for managing knowledge? Harvard Business Review, Vol. 77, No. 3, p. 196, 1999.

[3] Hubbard, R. G.,Capital-market imperfections and investment (No. w5996).National Bureau of economic research, 1997.

[4] Menor, L. J., Kristal, M. M.andRosenzweig, E. D., Examining the influence of operational intellectual capital on capabilities and performance, Manufacturing\& Service Operations Management, Vol. 9, No. 4, pp. 559-578, 2007. 
[5] Sarca, I. G., Silaghi-Perju, D. C., Draghici, A. and Taucean, I.,Organization Diagnosis Methodology for Future Investment Decisions Processes Preparation, Managing Innovation and Diversity in Knowledge Society Through Turbulent Time: Proceedings of the MakeLearn and TIIM Joint International Conference 2016, pp. 1133-1140, ToKnowPress, May 2016

[6] Shen, L., Fishbach, A., andHsee, C. K.. The Motivating-Uncertainty Effect: Uncertainty Increases Resource Investment in the Process of Reward Pursuit,Journal of Consumer Research, Vol. 41, No. 5, pp. 1301-1315.

[7] Vargas-Hernández, J. G., and Noruzi, M. R., How intellectual capital and learning organization can foster organizational competitiveness?.International Journal of Business and Management, Vol. 5, No. 4, p. 183, 2010. 